\title{
Direct Estimation of Maize Leaf Area Index as Influenced by Organic and Inorganic Fertilizer Rates in Guinea Savanna
}

\author{
Albert Berdjour ${ }^{1,3}$, Ibrahim Yakamba Dugje ${ }^{2}$, Nurudeen Abdul Rahman ${ }^{1}$, Daniel Asomaning Odoom ${ }^{3}$, \\ Alpha Yaya Kamara ${ }^{4} \&$ Sam Ajala ${ }^{5}$ \\ ${ }^{1}$ International Institute of Tropical Agriculture, Tamale, Ghana \\ ${ }^{2}$ University of Maiduguri, Maiduguri, Nigeria \\ ${ }^{3}$ University for Development Studies, Tamale, Ghana \\ ${ }^{4}$ International Institute of Tropical Agriculture, Kano, Nigeria \\ ${ }^{5}$ International Institute of Tropical Agriculture, Ibadan, Nigeria \\ Correspondence: Albert Berdjour, International Institute of Tropical Agriculture (IITA), P.O. Box TL 06, Tamale, \\ Ghana. E-mail: a.berdjour@cgiar.org
}

Received: February 26, 2020

Accepted: April 1, $2020 \quad$ Online Published: May 15, 2020

doi:10.5539/jas.v12n6p66

URL: https://doi.org/10.5539/jas.v12n6p66

The research is financed by SARD-SC Maize Project sponsored by Africa Development Bank (AfDB).

\begin{abstract}
Leaf area index (LAI) plays an important role in radiation capture, crop growth and yield formation. However, there is limited quantitative data on the influence of poultry manure (PM) and NPK fertilizer rate (NPK) on LAI, as estimated directly. Using a split-plot design with three replications, a field experiment was conducted to determine the effects of three PM rate $(0,2$ and $4 \mathrm{t} / \mathrm{ha})$ as main plot and three NPK rate (0:0:0, 60:30:30 and 120:60:60 $\mathrm{kg} \mathrm{N} \mathrm{P}_{2} \mathrm{O}_{5} \mathrm{~K}_{2} \mathrm{O} / \mathrm{ha}$ ) as sub plot, on LAI and maize grain yield. The maize was planted at a density of 106,666 plants/ha; two rows on a ridge, one plant per stand at $75 \times 25 \mathrm{~cm}$. Linear regression was used to establish predictive equations among correlated variables and to describe the degree of associations. The application of PM in maize increased $(\mathrm{p}<0.05)$ number of leaves/plant $(\mathrm{NL})$ at 8 and 10 weeks after sowing maize (WASM). NL, leaf area constant at 6 and 10 WASM, leaf area (LA) and LAI were significantly affected by NPK. LAI correlated positively with NL, LA and grain yield. The coefficient of determination between actual and estimated LA was in the range of $0.85-0.97$. The PM $\times$ NPK interaction was significant on maize grain yield. The results suggest that small-scale maize farmers faced with challenges in obtaining and transporting large quantities of poultry manure can use $2 \mathrm{t} \mathrm{PM} / \mathrm{ha}$ with either 60:30:30 $\mathrm{kg} \mathrm{N} \mathrm{P} \mathrm{O}_{5} \mathrm{~K}_{2} \mathrm{O} / \mathrm{ha}$ or 120:60:60 $\mathrm{kg} \mathrm{N} \mathrm{P}_{2} \mathrm{O}_{5}$ $\mathrm{K}_{2} \mathrm{O} /$ ha to increase grain yield of maize.
\end{abstract}

Keywords: direct estimation, poultry manure, NPK fertilizer, leaf area index, maize yield

\section{Introduction}

The total leaf area per unit horizontal surface area, is essentially expressed as leaf area index (LAI) (Myneni et al., 2002). LAI correlates with radiation capture, photosynthesis, energy exchange with the atmosphere as well as growth and yield formation (Tsialtas \& Maslaris, 2008). Therefore, leaf area (LA) measurements are required in most agronomic studies involving plant growth and yield analysis (Guo \& Sun, 2001). Several approaches; mainly indirect and direct methods of LA measurement have been developed (Blanco \& Folegatti, 2003). Although the former method; indirect estimation, has been recommended for monitoring LAI through time and across large spatial areas (Jonckheere et al., 2004), there is however the disadvantage of it being expensive and mostly non-existence in most developing countries (Addai \& Alimiyawo, 2015). Consequently, direct methods of estimating LAI have been widely adopted because of the unaffordability and difficulty in assessing leaf area instruments (Dugje \& Odo, 2006). The direct methods are mainly restricted to either the use of meter rule, tracing on paper sheets and/or graph paper to measures leaf area. However, each of these methods has a set of limitation. Due to complex leaf shapes, tracing leaf area on sheets or graphs is laborious. Similarly, since leaves 
are not rectangular, the use of meter rule as a means of determining leaf area by the length $\times$ width method makes it inappropriate.

Accordingly, Pal and Murari (1985) proposed the length $\times$ width $\times$ correction factor product method as a means for estimating leaf area. From this, Tanko and Hassan (2016), suggested a correction factor of 0.75 to be multiplied by the product of the length and maximum width for estimation of leaf area index in maize. However, no common multiplying factor can suffice for all situations since, the LAI of a particular genotype is strongly dependent on its leaf shape/size, the prevailing micro-climate and agronomic practices (Jonckheere et al., 2004). Confirming this, the accuracy of estimated leaf area, was reported by Zhang and Liu (2010) to be dependent on leaf shape variation due to differential genotypes. Addai and Alimiyawo (2015) observed a significant increase in leaf number, leaf area and leaf area index of sorghum under fertilized treatment than the control (unfertilised treatments). Similarly, maize crop differed in its ability to maintain LAI at different $\mathrm{N}$ fertilization levels (Pandey et al., 2000).

However, there is a dearth of information regarding the effect of organic and inorganic fertilizers on maize leaf area index. Such information could enhance the understanding on the relationship between the physiology and grain yield of maize as influenced by different fertility levels. We therefore, hypothesized that the leaf area index and grain yield of maize may be affected by the integrated use of poultry manure and NPK fertilizer rates.

\section{Materials and Method}

\subsection{Experimental Site}

The study was conducted in the 2016 cropping seasons at the Savanna Agricultural Research Institute experimental field at Nyankpala $\left(9^{\circ} 25^{\prime} 41^{\prime \prime} \mathrm{N} ; 0^{\circ} 58^{\prime} 42^{\prime \prime} \mathrm{W}\right)$ Guinea Savanna in northern Ghana. Mean annual total rainfall is about 800 to $1200 \mathrm{~mm}$, and is characteristically unimodal in distribution, which occurs from May to October (Figure 1), with a dry season characterized by harmattan winds occurring between October to April. Temperature is uniformly high throughout the year, with mean minimum and maximum annual values of $25^{\circ} \mathrm{C}$ and $38^{\circ} \mathrm{C}$ respectively (Figure 1). The soil of the study area was Haplic Lixisol (IUSS, 2014), with organic carbon of $<15 \mathrm{~g} / \mathrm{kg}$, total nitrogen of $<5 \mathrm{~g} / \mathrm{kg}$, exchangeable potassium of $<100 \mathrm{mg} / \mathrm{kg}$ and available phosphorus of $<10 \mathrm{mg} / \mathrm{kg}$ (Tetteh et al., 2016).

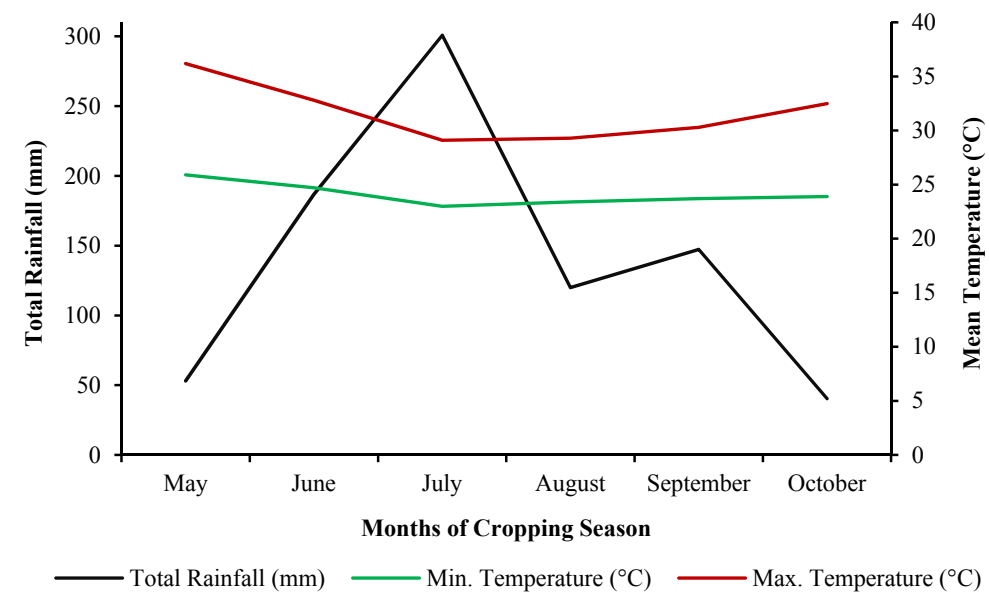

Figure 1. Rainfall and temperature variability at Nyankpala during 2016 cropping season (Savanna Agricultural Research Institute, SARI-Meteorological Division)

\subsection{Land Preparartion}

The land was prepared by preplant application of paraquat to control emerged weeds. Ridges at $75 \mathrm{~cm}$ apart were then constructed after land preparation; ploughing and harrowing.

\subsection{Experimental Design and Treatment}

The experimental design was a split-plot in a randomized complete block arrangement. The treatments replicated three times were made up of three poultry manure rates $(0,2$ and $4 \mathrm{t} / \mathrm{ha})$ as the main plot factor and three NPK fertilizer rates $\left(0: 0: 0,60: 30: 30\right.$ and 120:60:60 N: $\left.\mathrm{P}_{2} \mathrm{O}_{5}: \mathrm{K}_{2} \mathrm{O} \mathrm{kg} / \mathrm{ha}\right)$ as sub-plot factor. Intermediate maturing maize type: IWD C3 Syn F2, was used for the study. Sub-plot size was $3 \mathrm{~m} \times 5 \mathrm{~m}$ and an alley of $1 \mathrm{~m}$ and $2 \mathrm{~m}$ 
separated sub-plots within and between replications respectively. The nutrient composition of the applied poultry manure are shown in Table 1.

Table 1. Chemical properties of applied poultry manure

\begin{tabular}{lll}
\hline Parameters & Values & Units \\
\hline $\mathrm{pH}$ & 6.83 & \\
$\mathrm{EC}$ & 8.70 & $\mathrm{dsm}^{-1}$ \\
${ }^{\mathrm{a}} \mathrm{OC}$ & 3.51 & $\%$ \\
${ }^{\mathrm{b}} \mathrm{OM}$ & 6.05 & $\%$ \\
${ }^{\mathrm{c}} \mathrm{N}$ & 0.63 & $\%$ \\
${ }^{\mathrm{d}} \mathrm{P}$ & 13.88 & $\mathrm{mg} / \mathrm{kg}$ \\
${ }^{\mathrm{e}} \mathrm{K}$ & 154.92 & $\mathrm{mg} / \mathrm{kg}$ \\
${ }^{\mathrm{f}} \mathrm{Ca}$ & 3.63 & $\mathrm{Cmol}+\mathrm{kg}$ \\
${ }^{\mathrm{g}} \mathrm{Mg}$ & 1.72 & $\mathrm{Cmol}+/ \mathrm{kg}$ \\
\hline
\end{tabular}

Note. ${ }^{\mathrm{a}} \mathrm{OC}=$ organic carbon, ${ }^{\mathrm{b}} \mathrm{OM}=$ organic matter, ${ }^{\mathrm{c}} \mathrm{N}=$ nitrogen, ${ }^{\mathrm{d}} \mathrm{P}=$ available phosphorus, ${ }^{\mathrm{e}} \mathrm{K}=$ available potassium, ${ }^{\mathrm{f}} \mathrm{Ca}=$ calcium, ${ }^{\mathrm{g}} \mathrm{Mg}=$ Magnesium.

\subsection{Agronomic Practices}

A shallow furrow on top of the ridge was drilled and poultry manure incorporated into the respective plots at depth of about 5 to $7 \mathrm{~cm}$ deep one week before sowing the maize crop. The maize was planted at a density of 106,666 plants/ha (two rows on a ridge, one plant per stand at $75 \times 25 \mathrm{~cm}$ with triangular stand density. A compound fertilizer, $\mathrm{N}_{2} \mathrm{O}_{5} \mathrm{~K}_{2} \mathrm{O}$ (15-15-15) was applied, equidistantly on the crest of the ridge in-between the two maize rows, 10 days after sowing. Sulphate of ammonium $(24 \%$ N) was applied as top dress 20 days after the basal fertilizer application. Organic manure and NPK fertilizer were not applied to the zero treatment plots. Weed was controlled manually at 3 and 6 weeks after sowing maize (WASM), as required, to avoid weed build up to critical levels of infestation (Akobundu, 1987).

\subsection{Data Collection}

\subsubsection{Leaf Parameters}

Data on leaf parameters including number of leaves/plants, leaf area, leaf area constant and leaf area index were determined biweekly, starting from 6 WASM to 10 WASM, using the method suggested by Dugje (1992). Number of leaves/plant was determined by counting all fully expanded green leaves observed for each of the three selected and tagged plants in each sub-plot. The averged number of leaves/plant were then calculated for each sub-plot. The three randomly selected and tagged plants in each sub-plot, then had their three (3) fully expanded green leaves measured and removed across leaf positions (upper, middle and lower). From these measurements, leaf area and leaf area constant were determined for each sub-plot. The outline of each leaf was traced on a graph and all squares covered by the leaf outline were counted to determine the actual leaf area $\left(\mathrm{cm}^{2}\right)$ The length and maximum width of each leaf outline on the graph were determined with measuring tape to obtain the estimated leaf area $\left(\mathrm{cm}^{2}\right)$. Based on this, (1) a linear regression model between actual and estimated leaf area was developed and (2) leaf area constant for each leaf sample was estimated by dividing the actual leaf area by the estimated leaf area and these were averaged over the number of leaf samples per plant. The single leaf area was then calculated using the formulae:

$$
\text { Single leaf area }\left(\mathrm{cm}^{2}\right)=\mathrm{L} \times \mathrm{W} \times \mathrm{K}
$$

Where, $\mathrm{L}=$ Leaf length $(\mathrm{cm}), \mathrm{W}=$ Maximum leaf width $(\mathrm{cm}), \mathrm{K}=$ Leaf area constant.

From this the leaf area index was estimated using the formulae suggested by (Dugje, 1992):

$$
\mathrm{LAI}=(\mathrm{P} \times \mathrm{L} \times \mathrm{A}) /(\mathrm{GA})
$$

Where, LAI = Leaf area index, $\mathrm{P}=$ Plant population/ground area (ha), $\mathrm{L}=$ Number of fully expanded green leave/plant, $\mathrm{A}=$ Single leaf area $\left(\mathrm{cm}^{2}\right), \mathrm{GA}=$ Ground area or hectare.

According to Welles (1990), since leaf area index is defined as the relative area of crop foliage per unit area of ground, and since leaf area was measured in square centimetres $\left(\mathrm{cm}^{2}\right)$, hence,

$$
\mathrm{LAI}=(\mathrm{P} \times \mathrm{L} \times \mathrm{A}) /\left(10^{7}\right)
$$




\subsubsection{Grain Yield Productivity}

The grain yield was measured from the two centre rows $\left(7.1 \mathrm{~m}^{2}\right)$ of each sub-plot. The cobs were harvested at physiological maturity, dehusked, oven dried at $65{ }^{\circ} \mathrm{C}$ to a moisture content of $13 \%$ before shelling to measure grain yield.

\subsection{Statistical Analysis}

The General Analysis of Variance (ANOVA) procedure of the statistix 10 analytical package (2013) for windows, was used to analyse the number of leaves per plant, leaf area, leaf area constant, leaf area indices and grain yield data. Least significant difference (LSD) was used to separate treatment means of significant difference at $5 \%$ probability level.

Spearman correlation analysis was performed to determine relationship among number of leaves, leaf area, leaf area constant, leaf area indices and grain yield. Parameters with correlation values of 0.50 and above were considered to be best fitted and less than 0.50 considered non-best fit. Linear regression was used to establish predictive equations among correlated variables.

\section{Results}

\subsection{Number of Leaves/Plants}

Poultry manure (PM) and NPK fertilizer rates did not interact significantly to affect the expression of number of leaves/plants at all sampling periods (6, 8 and 10 WASM) (Table 2). The effect of PM, except at 6 WAPM, significantly influenced number of leaves/plants at both 8 and 10 WAPM. However, at all sampling periods, the application of PM at $0 \mathrm{t} / \mathrm{ha}$ (control) produced the lowest number of leaves/plant than the other levels of PM rates. Application of NPK fertilizer had significant effect on the number of leaves per plant, such that the application of 60-30-30 or 120-60-60 $\mathrm{kg} \mathrm{N} \mathrm{P}_{2} \mathrm{O}_{5} \mathrm{~K}_{2} \mathrm{O}$ /ha fertilizer increased $(\mathrm{p}<0.01)$ the number of leaves per plant than the control treatment at all sampling periods (Table 2).

Table 2. Number of leaves/plant as affected by poultry manure and NPK fertilizer rate

\begin{tabular}{|c|c|c|c|}
\hline & \multicolumn{3}{|c|}{ Number of leaves } \\
\hline & 6 WASM & 8 WASM & 10 WASM \\
\hline \multicolumn{4}{|l|}{ Poultry manure rate $(P M ; t / h a)$} \\
\hline 0 & $4.33^{\mathrm{a}}$ & $9.77^{\mathrm{b}}$ & $8.88^{\mathrm{b}}$ \\
\hline 2 & $4.66^{\mathrm{a}}$ & $11.00^{\mathrm{a}}$ & $10.33^{\mathrm{a}}$ \\
\hline 4 & $4.88^{\mathrm{a}}$ & $11.00^{\mathrm{a}}$ & $10.22^{\mathrm{a}}$ \\
\hline $\operatorname{LSD}(0.05)$ & 0.59 & 0.85 & 0.85 \\
\hline$p$-value & ns & $*$ & $*$ \\
\hline \multicolumn{4}{|l|}{$\mathrm{NPK}$ rate $\left(\mathrm{NP}_{2} \mathrm{O}_{5} \mathrm{~K}_{2} \mathrm{O} ; \mathrm{kg} / \mathrm{ha}\right)$} \\
\hline $0: 0: 0$ & $3.88^{\mathrm{b}}$ & $9.55^{\mathrm{b}}$ & $9.00^{\mathrm{b}}$ \\
\hline $60: 30: 30$ & $5.00^{\mathrm{a}}$ & $11.00^{\mathrm{a}}$ & $10.33^{\mathrm{a}}$ \\
\hline $120: 60: 60$ & $5.00^{\mathrm{a}}$ & $11.11^{\mathrm{a}}$ & $10.22^{\mathrm{a}}$ \\
\hline $\operatorname{LSD}(0.05)$ & 0.62 & 0.82 & 0.85 \\
\hline$p$-value & $* *$ & $* *$ & $*$ \\
\hline \multicolumn{4}{|l|}{$P M \times N P K$} \\
\hline$p$-value & ns & ns & ns \\
\hline
\end{tabular}

\subsection{Leaf Area Constant}

The results of leaf area constant computed for leaf area estimation are shown in Table 3. 
Table 3. Leaf area constant as affected by poultry manure and NPK fertilizer rate

\begin{tabular}{|c|c|c|c|}
\hline & \multicolumn{3}{|c|}{ Leaf area constants } \\
\hline & 6 WASM & 8 WASM & 10 WASM \\
\hline \multicolumn{4}{|l|}{ Poultry manure rate $(P M ; t / h a)$} \\
\hline 0 & $0.78^{\mathrm{a}}$ & $0.78^{\mathrm{a}}$ & $0.74^{\mathrm{a}}$ \\
\hline 2 & $0.79^{\mathrm{a}}$ & $0.78^{\mathrm{a}}$ & $0.73^{\mathrm{a}}$ \\
\hline 4 & $0.79^{\mathrm{a}}$ & $0.76^{\mathrm{a}}$ & $0.72^{\mathrm{a}}$ \\
\hline $\operatorname{LSD}(0.05)$ & 0.01 & 0.02 & 0.01 \\
\hline$p$-value & ns & ns & ns \\
\hline \multicolumn{4}{|l|}{$\mathrm{NPK}$ rate $\left(\mathrm{NP}_{2} \mathrm{O}_{5} \mathrm{~K}_{2} \mathrm{O} ; \mathrm{kg} / \mathrm{ha}\right)$} \\
\hline $0: 0: 0$ & $0.73^{\mathrm{b}}$ & $0.75^{\mathrm{a}}$ & $0.70^{\mathrm{b}}$ \\
\hline $60: 30: 30$ & $0.81^{\mathrm{a}}$ & $0.77^{\mathrm{a}}$ & $0.74^{\mathrm{a}}$ \\
\hline $120: 60: 60$ & $0.83^{\mathrm{a}}$ & $0.80^{\mathrm{a}}$ & $0.76^{\mathrm{a}}$ \\
\hline $\operatorname{LSD}(0.05)$ & 0.02 & 0.02 & 0.01 \\
\hline$p$-value & $* *$ & ns & $* * *$ \\
\hline \multicolumn{4}{|l|}{$P M \times N P K$} \\
\hline$p$-value & ns & ns & ns \\
\hline
\end{tabular}

Note. ${ }^{* * *} P<0.0001,{ }^{* *} P<0.01,{ }^{\mathrm{ns}} P>0.05$.

On all sampling periods PM $\times$ NPK interaction, likewise the effect of PM was not significant on leaf area constant; however, the effect of NPK was significant on leaf area constant at 6 and 10 WASM (Table 3). Leaf area constants of NPK fertilizer rates at 60:30:30 $\mathrm{kg} \mathrm{N} \mathrm{P}_{2} \mathrm{O}_{5} \mathrm{~K}_{2} \mathrm{O} / \mathrm{ha}$ and 120:60:60 $\mathrm{kg} \mathrm{N} \mathrm{P}_{2} \mathrm{O}_{5} \mathrm{~K}_{2} \mathrm{O} / \mathrm{ha}$ increased significantly compared with the control in both sampling periods (Table 3 ).

\subsection{Leaf Area}

Interaction effect of PM and NPK was not significant on leaf area in all sampling days, likewise PM effects (Table 4).

Table 4. Leaf area as affected by poultry manure and NPK fertilizer rate

\begin{tabular}{llll}
\hline & \multicolumn{3}{c}{ Leaf area $\left(\mathrm{cm}^{2}\right)$} \\
\cline { 2 - 4 } Poultry manure rate $(P M ; t / h a)$ & 6 WASM & 8 WASM & 10 WASM \\
0 & & & \\
2 & $196.96^{\mathrm{a}}$ & $356.34^{\mathrm{a}}$ & $341.96^{\mathrm{a}}$ \\
4 & $252.01^{\mathrm{a}}$ & $397.72^{\mathrm{a}}$ & $394.20^{\mathrm{a}}$ \\
LSD $(0.05)$ & $268.36^{\mathrm{a}}$ & $386.44^{\mathrm{a}}$ & $370.70^{\mathrm{a}}$ \\
$p$-value & 41.61 & 23.41 & 36.68 \\
$N P K$ rate $\left(N P_{2} \mathrm{O}_{5} K_{2} O ; \mathrm{kg} / \mathrm{ha}\right)$ & $\mathrm{ns}$ & $\mathrm{ns}$ & $\mathrm{ns}$ \\
$0: 0: 0$ & & & \\
$60: 30: 30$ & $168.62^{\mathrm{b}}$ & $231.54^{\mathrm{b}}$ & $210.60^{\mathrm{b}}$ \\
$120: 60: 60$ & $271.96^{\mathrm{a}}$ & $439.31^{\mathrm{a}}$ & $431.17^{\mathrm{a}}$ \\
LSD $(0.05)$ & $276.74^{\mathrm{a}}$ & $459.66^{\mathrm{a}}$ & $455.09^{\mathrm{a}}$ \\
$p$-value & 26.74 & 22.09 & 21.64 \\
$P M \times N P K$ & $* *$ & $* *$ & $* * *$ \\
$p$-value & & & $\mathrm{ns}$ \\
\hline$P<0.0001, * * P<0.01, \mathrm{~ns} P>0.05$ & & & $\mathrm{~ns}$
\end{tabular}

For the effects of NPK fertilizer rates, the analysis of variance showed a significant difference in maize leaf area at all sampling periods (Table 4), such that, the application of 60-30-30 and 120-60-60 kg N $\mathrm{P}_{2} \mathrm{O}_{5} \mathrm{~K}_{2} \mathrm{O} / \mathrm{ha}$ resulted in higher $(\mathrm{p}<0.01)$ leaf area for maize, than the control treatment (Table 4$)$. 


\subsection{Leaf Area Index}

The influence of PM and NPK fertilizer rates on leaf area indices are presented in Table 5. PM $\times$ NPK interaction, likewise PM effect did not influence $(\mathrm{P}>0.05)$ leaf area indices of maize at all sampling periods.

However, leaf area indices were significantly affected by NPK fertilizer levels at all sampling periods (Table 5). The lowest leaf area indices value was observed under the control, while NPK application rate of 120:60:60 kg N $\mathrm{P}_{2} \mathrm{O}_{5} \mathrm{~K}_{2} \mathrm{O} /$ ha contributed to the highest leaf area index values (Table 5).

Table 5. Leaf area index as affected by poultry manure and NPK fertilizer rate

\begin{tabular}{|c|c|c|c|}
\hline & \multicolumn{3}{|c|}{ Leaf area index } \\
\hline & 6 WASM & 8 WASM & 10 WASM \\
\hline \multicolumn{4}{|l|}{ Poultry manure rate $(P M ; t / h a)$} \\
\hline 0 & $0.75^{\mathrm{a}}$ & $2.68^{\mathrm{b}}$ & $2.50^{\mathrm{a}}$ \\
\hline 2 & $1.01^{\mathrm{a}}$ & $3.46^{\mathrm{a}}$ & $3.28^{\mathrm{a}}$ \\
\hline 4 & $1.10^{\mathrm{a}}$ & $3.22^{\mathrm{ab}}$ & $2.98^{\mathrm{a}}$ \\
\hline $\operatorname{LSD}(0.05)$ & 0.16 & 0.22 & 0.30 \\
\hline$p$-value & ns & ns & ns \\
\hline \multicolumn{4}{|l|}{$\mathrm{NPK}$ rate $\left(\mathrm{NP}_{2} \mathrm{O}_{5} \mathrm{~K}_{2} \mathrm{O} ; \mathrm{kg} / \mathrm{ha}\right)$} \\
\hline $0: 0: 0$ & $0.53^{\mathrm{b}}$ & $1.67^{\mathrm{b}}$ & $1.41^{\mathrm{b}}$ \\
\hline $60: 30: 30$ & $1.14^{\mathrm{a}}$ & $3.62^{\mathrm{a}}$ & $3.45^{\mathrm{a}}$ \\
\hline $120: 60: 60$ & $1.20^{\mathrm{a}}$ & $4.08^{\mathrm{a}}$ & $3.90^{\mathrm{a}}$ \\
\hline $\operatorname{LSD}(0.05)$ & 0.14 & & \\
\hline$p$-value & $* *$ & $* * *$ & $* * *$ \\
\hline \multicolumn{4}{|l|}{$P M \times N P K$} \\
\hline$p$-value & ns & ns & ns \\
\hline
\end{tabular}

\subsection{Grain Yield}

$\mathrm{PM} \times$ NPK interaction, effect of PM and NPK effect were significant on grain yield. The maize grain yield of PM rate at $2 \mathrm{t} / \mathrm{h}$ combined with NPK fertilizer rate at 120:60:60 $\mathrm{kg} \mathrm{N} \mathrm{P}_{2} \mathrm{O}_{5} \mathrm{~K}_{2} \mathrm{O} / \mathrm{ha}$ increased significantly compared with all other combinations of PM and NPK fertilizer rates (Figure 2). Maize grain yield (MGY) was positively correlated with number of leaves at 10 WASM (NL-10), leaf area at 8 WASM (LA-8), leaf area index at 8 WASM (LAI-8) and 10 WASM (LAI-10) (Figure 3). This indicates that when NL-10, LA-8, LAI-8 and LAI-10 increase MGY also increases. This relationship could be predicted from the general linear regression model:

$$
\mathrm{Y}_{\mathrm{MGY}}=-5843.4+695.2_{\mathrm{NL}-10}+11.8_{\mathrm{LA}-8}+209.5_{\mathrm{LAI}-8}-1039.5_{\mathrm{LAI}-10}, \mathrm{r}^{2}=0.36
$$

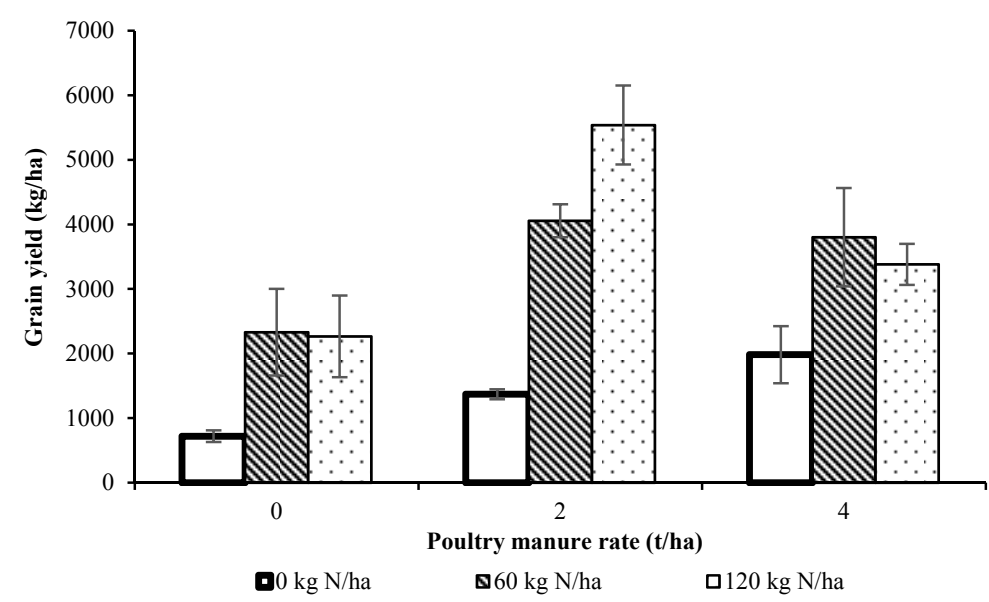

Figure 2. The interaction effect of poultry manure $\times$ NPK fertilizer rate on grain yield of maize. Bars represent standard error of mean (S.E.M.) 


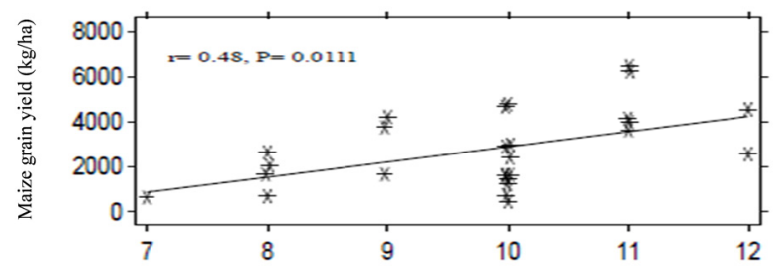

Number of leaves/plant at 10 weeks after planting maize (WAPM)

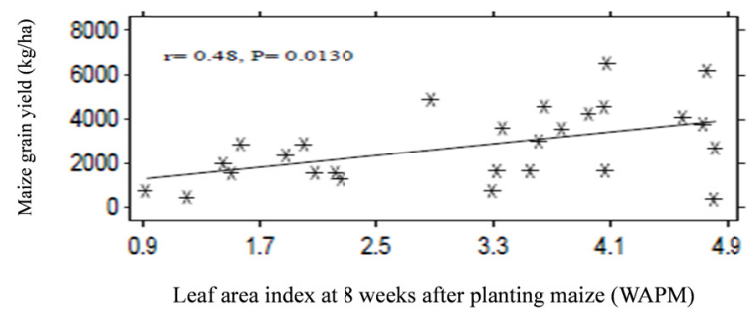

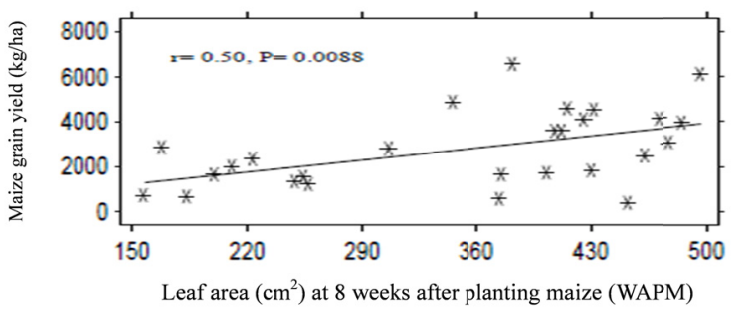

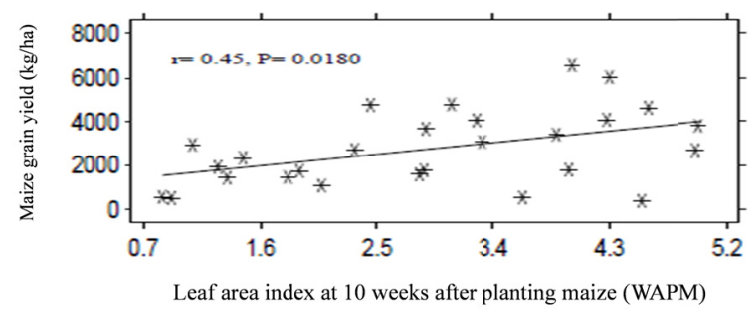

Figure 3. Maize grain yield relationship with number of leaves/plant at 10 WAPM, leaf area at 8 WAPM, Leaf area index at 8 and 10 WAPM

\subsection{Relationship Between Actual and Estimated Leaf Area}

Figure 4 depicts the relationships between actual leaf area (dependent variable) and estimated leaf area (independent variable) at three growth stages: 6, 8 and 10 WASM. The figure shows that, the two sets of calculated leaf area $\left(\mathrm{cm}^{2}\right)$ are strongly related and as such the leaf area $\left(\mathrm{cm}^{2}\right)$ results, obtained by the length $\times$ width method (estimated leaf area) are as good as those obtained by the graph estimated method (actual leaf area). At all growth stages, the coefficient of determination varied between 0.85-0.97.
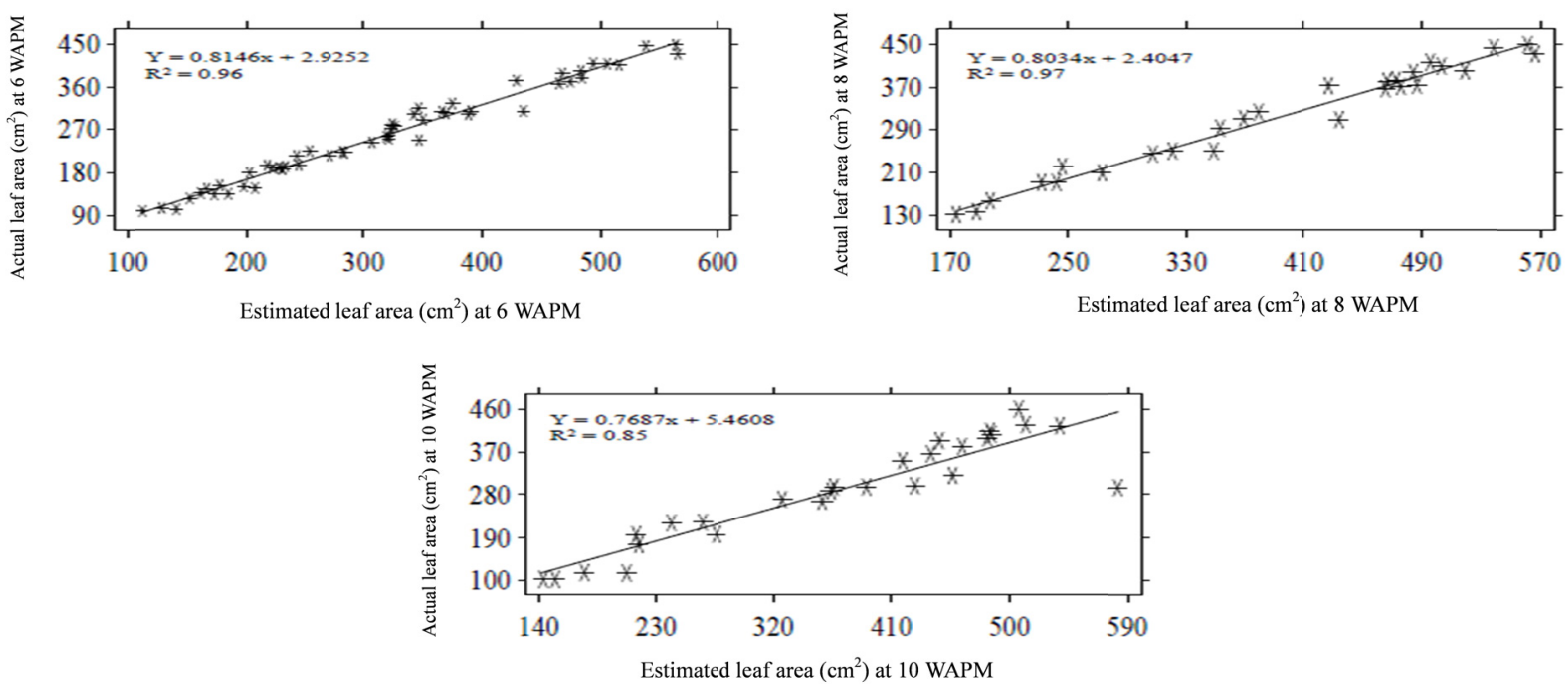

Figure 4. Relationship between leaf area measured by length $\times$ width method (Estimated) and that determined by graphical method (Actual) $(n=243)$

\section{Discussion}

\subsection{Number of Leaves/Plants}

Number of leaves/plant is an important crop parameter that promotes photosynthetic activity. In this study, significant effect of PM on number of leaves/plant was revealed from 8-10 WASM. This could be attributed to the slow mineralization process that accompanies the use of organic manure. This slow release of plant nutrient might have led to the non-significant effect of PM on number of leaves per plant, early in the crop growth stage, i.e., 6 WASM. This result is in consonance with the findings of witness et al. (2015), who reported a non-significant organic manure treatment effect on number of leaves of rape from weeks 1-6. 
The significant effect of NPK fertilizer rate on number of leaves/plant at the various growth stages could possibly be due to the readily supply of available plant nutrients by the inorganic fertilizer over a short period. This result agrees with earlier findings that NPK fertilizer application could lead to a rapid and positive effect on maize leave number expression (Adiaha, 2016). However, the decrease in number of leaves/plant irrespective of NPK fertilizer levels at 10 WAPM could be attributed to senescence and abscission of lower leaves as associated with maize, late in its growth stage.

\subsection{Leaf Area Constant}

Musa and Usman (2016), observed a range of 0.68-0.81 as leaf area coefficients for estimating leaf area index in maize. In this study, the averaged leaf area constants across the NPK fertilizer rates ranged from 0.73-0.83 at 6 WASM and 0.70-0.76 at 10 WASM, with higher mean values been recorded under the application rate of 120:60:60 kg N $\mathrm{P}_{2} \mathrm{O}_{5} \mathrm{~K}_{2} \mathrm{O} / \mathrm{ha}$. This trend of results at both growth stages, agrees with studies carried out by Marshal (1968) who observed that leaf area constant changes during plant growth and along with changes in the micro-climate condition. Studies of Chanda et al. (1995) also support this conclusion. However, higher values of leaf area constant observed at 6 WASM disagrees with earlier reports that, due to maximum leaf production and expansion at peak growth stage ( 8 Weeks after Sowing) of millet, higher leaf area coefficients were strongly associated with higher leaf area (Dugje \& Odo, 2006).

\subsection{Leaf Area}

Leaf area increased with time and peaked at 8 WASM. Mean values ranging between $211.54 \mathrm{~cm}^{2}$ and $429.66 \mathrm{~cm}^{2}$ for the control and the higher level of NPK was observed respectively. These results agree with those of Oscar and Tollenaar (2006). Higher leaf area values as influenced by NPK application rate of 120:60:60 kg NPK/ha could possibly be due to the positive effect of nitrogen on cell division and elongation resulting in increased leaf length and rapid leaf development (Chiesa et al., 2000). However, leaf area did not differ significantly amongst 60:30:30 and 120:60:60 $\mathrm{kg} \mathrm{N} \mathrm{P}_{2} \mathrm{O}_{5} \mathrm{~K}_{2} \mathrm{O} / \mathrm{ha}$ at all sampling periods. This observation lacks agreement with Chaudhary and Jamil (1998) who reported that, higher doses of nitrogen increases plant growth rather than yield.

\subsection{Leaf Area Index}

The influence of NPK on leaf area indices revealed maximum leaf area index under the highest level of NPK: 120:60:60 $\mathrm{kg} \mathrm{N} \mathrm{P}_{2} \mathrm{O}_{5} \mathrm{~K}_{2} \mathrm{O} / \mathrm{ha}$. Leaf area indices increased with the application of NPK compared with the control. The above results indicated that, achieving maximum leaf area indices requires higher plant nutrients supply. These findings agree with earlier reports that, $\mathrm{N}$ fertilizer application at higher doses, increased leaf area index by delaying leaf senescence, sustaining leaf photosynthesis and maintenance of leaf area duration ('stay-green') (G. P. Zhang \& G. H. Zhang, 1998; Dugje \& Odo 2006).

Maximum values of leaf area indices were generally observed at 8 WASM by all levels of NPK. This result indicated that, higher values attain at 8 WASM by both number of leaves/pant and leaf area may have contributed to the realization of higher leaf area indices value at 8 WASM. Studies of Dugje and Odo (2006) also support this conclusion.

\subsection{Grain Yield}

$\mathrm{PM} \times$ NPK interaction on the averaged, increase grain yield by $165 \%$ compared with the PM application and $85 \%$ compared with the application of NPK. The synergistic effect of the PM and NPK fertilizer was more evident when NPK fertilizer at either 60-30-30 or 120-60-60 kg N $\mathrm{P}_{2} \mathrm{O}_{5} \mathrm{~K}_{2} \mathrm{O} / \mathrm{ha}$ was combined with PM at $2 \mathrm{t} / \mathrm{ha}$. This PM $\times$ NPK fertilizer interaction on grain yield could be due to the continuous supply of plant nutrients to the maize plants as the combination of NPK fertilizer and PM released plant nutrients slowly over long period of time. This supports earlier reports on the synergistic effect of combined application of animal manure and inorganic fertilizer application in northern Ghana (Abdul Rahman et al., 2014, 2019). The variation in maize grain yield could also be attributed to the positive relation between the leaf parameters (NL, LA, and LAI); $\mathrm{Y}_{\mathrm{MGY}}$ $=-5843.4+695.2_{\mathrm{NL}-10}+11.8_{\mathrm{LA}-8}+209.5_{\mathrm{LAI}-8}-1039.5_{\mathrm{LAI}-10}, \mathrm{r}^{2}=0.36$, making them more efficient in the capture and conversion of solar radiation into assimilates. Conversely, Lambert et al. (2014) associated significantly high grain yield with low leaf area in maize hybrids.

\section{Conclusion}

The application of poultry manure and NPK fertilizer increased number of leaves/plant, leaf area constant, leaf area and leaf area index of maize relative to their respective control treatments at all sampling periods. The relationship between actual leaf area and estimated leaf area were consistently close to one, indicating a strong relationship between the two sets of calculated leaf area $\left(\mathrm{cm}^{2}\right)$. The interaction of PM $\times$ NPK was significant on grain yield, however using poultry manure at $2 \mathrm{t} / \mathrm{ha}$ with NPK fertilizer increased grain yield better than $4 \mathrm{t} / \mathrm{ha}$ 
with NPK fertilizer. The results suggest that small-scale maize farmers faced with challenges in obtaining and transporting large quantities of organic manure, coupled with their resource status, can use $2 \mathrm{tPM} / \mathrm{ha}$ with either 60:30:30 kg N P $\mathrm{O}_{5} \mathrm{~K}_{2} \mathrm{O} /$ ha or 120:60:60 $\mathrm{kg} \mathrm{N} \mathrm{P}_{2} \mathrm{O}_{5} \mathrm{~K}_{2} \mathrm{O} /$ ha fertilizer rate to increase grain yield of maize.

\section{Acknowledgements}

The authors acknowledge and appreciate funding from SARD-SC Maize Project sponsored by Africa Development Bank (AfDB) with backstopping from the the International Institute of Tropical Agriculture (IITA). Collaborative staff, field and laboratory support from Savanna Agricultural Research Institue (SARI) Tamale is greatly appreciated.

\section{References}

Abdul Rahman, N., Fosu, M., \& Tetteh, F. M. (2014). Effect of Tillage System and Soil Amendment on growth and yield of Maize in Northern Ghana. Journal of Agronomy, 13, 79-84. https://doi.org/10.3923/ja.2014. 79.84

Abdul Rahman, N., Larbi, A., Opoku, A., Tetteh, F. M., \& Hoeschle-Zeledon, I. (2019). Crop-livestock interaction effect on soil quality and maize yield in Northern Ghana. Agronomy Journal, 111, 907-916. https://doi.org/10.2134/agronj2018.08.0523

Addai, I. K., \& Alimiyawo, M. (2015). Graphical determination of leaf area index and its relationship with growth and yield parameters of Sorghum (Sorghum bicolor L. Moench) as affected by fertilizer application. Journal of Agronomy, 14(4), 272. https://doi.org/10.3923/ja.2015.272.278

Adiaha, M. S. (2016). Influence of different soil types and mineral fertilizer on maize growth for effective production, soil fertility improvement and food security. World Scientific News, 55, 137-167.

Akobundu, I. O. (1987). Weed Science in the Tropics, Principles and Practice. John Willey and Sons.

Blanco, F. F., \& Folegatti, M. V. (2003). A new method for estimating the leaf area index of cucumber and tomato plants. Horticultura Brasileira, 21(4), 666-669. https://doi.org/10.1590/S0102-05362003000400019

Chanda, S. V., Sigh, Y. D., Chandhuri, B. B., \& Vaishna, P. P. (1995). Leaf area determination in pearl millet using linear measurements. Photosynthetica, 19, 434-447.

Chaudhary, A. U., \& Jamil, M. (1998). Determination of optimum level of nitrogen and its effect on maize (Zea mays L.). Pakistan Journal of Biological Science, 1, 360-362.

Chiesa, A., Mateoes, E., de Grazia, J., \& Tittonel, P. (2000). Plant population and fertilization influence on sweet corn yield. Hortic Argentine, 18, 44-45.

Dugje, I. Y. (1992). Effects of row spacing on growth, development and yield of Masakwa Sorghum (Sorghum bicolor (L.) Monech) on a semi-arid vertisols. University of Maiduguri, Nigeria.

Dugje, I. Y., \& Odo, P. E. (2006). Variety and inter-row spacing influence on direct estimation of leaf area index of pearl millet. Journal of Sustainable Tropical Agricultural Research, 18, 27-34.

Guo, D. P., \& Sun, Y. Z. (2001). Estimation of leaf area of stem lettuce (Lactuca sativa var angustana) from linear measurements. Indian Journal of Agricultural Science, 71(7), 483-486. https://doi.org/10.12691/ plant-3-2-3

Jonckheere, I., Fleck, S., Nackaerts, K., Muys, B., Coppin, P., Weiss, M., \& Baret, F. (2004). Review of methods for in situ leaf area index determination: Part I. Theories, sensors and hemispherical photography. Agricultural and Forest Meteorology, 121(1-2), 19-35. https://10.1016j.agrformet.2003.08.027

Lambert, J. R., Mansfield, D. B., \& Mumm, H. R. (2014). Effect of leaf area on maize productivity. Maydica, 59(1), 58-64.

Marshal, J. K. (1968). Method of leaf area measuremnet of large and small leaf samples. Photosynthetica, 2(41).

Myneni, R. B., Hoffman, S., Knyazikhin, Y., Privette, J. L., Glassy, J., Tian, Y., \& Smith, G. R. (2002). Global products of vegetation leaf area and fraction absorbed PAR from year one of MODIS data. Remote Sensing of Environment, 83(1-2), 214-231. https://10.1016/S0034-4257(02)00074-3

Oscar, R. V., \& Tolenaar, M. (2006). Effect of genotype, nitrogen, plant density and row spacing on the area per-leaf profile in maize. Agronony Journal, 98, 94-99. https://10.2134/agronj2005.0111

Pal, U. R., \& Murari, K. (1985). Length and width measurement for estimating leaf area of grain sorghum. Samaru Journal of Agricultural Research, 3(1), 109-112. 
Pandey, R. K., Maranville, J. W., \& Chetima, M. M. (2000). Deficit irrigation and nitrogen effects on maize in a Sahelian environment II. Shoot growth, nitrogen uptake and water extraction. Agricultural Water Management, 46, 15-27. https://doi.org/10.1016/S0378-3774(00)00074-3

Tanko, U. M., \& Hassan, U. T. (2016). Leaf area determination for maize (Zea mays L.), Okra (Abelmoschus esculentus L.) and Cowpea (Vigna unguiculata L.) Crops using Linear Measurements. Journal of Biology, Agriculture and Healthcare, 6(4), 103-111.

Tetteh, F., Larbi, A., Nketia, K. A., Senayah, J. K., Hoeschle-Zeledon, I., \& Abdul-Rahman, N. (2016). Suitability of soils for cereal cropping in Northern Ghana. Evaluations and Recommendations. Ibadan, Nigeria: International Institute for Tropical Agriculture (IITA) Report.

Tsialtas, J. T., \& Maslaris, N. (2008). Evaluation of a leaf area prediction model proposed for sunflower. Photosynthetica, 46(2), 294-297. https://doi.org/10.1007/s11099-008-0052-6

Welles, J. M. (1990). Some indirect methods of estimating canopy structure. Remote Sensing Reviews, 5(1), 31-43. https://doi.org/10.1080/02757259009532120

Witness, M., Mosanarea, M., Thembirikosi, M., \& Gabatshale M. L. (2015). Effect of different application rates of organic fertilizer on growth, development and yield of rape (Brassica napus L.). IJIRSET, 4, 1-9. https://doi.org/10.1155/2018/2351204

Zhang, G. P., \& Zhang, G. H. (1996). Studies on genotype difference in nitrogen use efficiency of wheat. Plant Nutrition \& Fertilizer Science, 4, 407-409.

Zhang, L., \& Liu, X. S. (2010). Non-destructive leaf area estimation for Berbenia purpurascens across timberline ecotone, southeast Tibet. Annales Botanici Fennici, 47(5), 346-352. https://doi.org/10.5735/085.047.0504

\section{Copyrights}

Copyright for this article is retained by the author(s), with first publication rights granted to the journal.

This is an open-access article distributed under the terms and conditions of the Creative Commons Attribution license (http://creativecommons.org/licenses/by/4.0/). 